\title{
Disgust, humiliation and shame in the everyday life of homeless crack users
}

Nojo, humilhação e vergonha no cotidiano de usuários de crack em situação de rua

\section{Taniele Rui}

\section{(2) OpenEdition \\ Journals}

Electronic version

URL: https://journals.openedition.org/aa/8929

DOI: $10.4000 /$ aa. 8929

ISSN: 2357-738X

\section{Publisher}

Programa de Pós-Graduação em Antropologia Social (UnB)

Printed version

Number of pages: 108-129

ISSN: 0102-4302

\section{Electronic reference}

Taniele Rui, "Disgust, humiliation and shame in the everyday life of homeless crack users", Anuário Antropológico [Online], v.46 n.3 | 2021, Online since 28 September 2021, connection on 01 October 2021. URL: http://journals.openedition.org/aa/8929 ; DOI: https://doi.org/10.4000/aa.8929

\section{(c) $($ () $\odot$}

Anuário Antropológico is licensed under a Creative Commons Atribuição-Uso Não-Comercial-Proibição de realização de Obras Derivadas 4.0 International. 


\section{Anuário Antropológico}

v.46 n.3 | 2021

2021/v.46 n.3

\section{Disgust, humiliation and shame in the everyday life of homeless crack users}

Taniele Rui

\section{CpenEdition \\ Journals}

\section{Edição electrônica}

URL: http://journals.openedition.org/aa/8929

DOI: $10.4000 / a a .8929$

ISSN: 2357-738X

\section{Editora}

Programa de Pós-Graduação em Antropologia Social (UnB)

\section{Referência eletrônica}

Taniele Rui, «Disgust, humiliation and shame in the everyday life of homeless crack users», Anuário Antropológico [Online], v.46 n.3 | 2021. URL: http://journals.openedition.org/aa/8929 ; DOI: https://doi. org/10.4000/aa.8929

\section{(c) (i) $(9)$}

Anuário Antropológico is licensed under a Creative Commons. Atribuição-SemDerivações-SemDerivados CC BY-NC-ND 


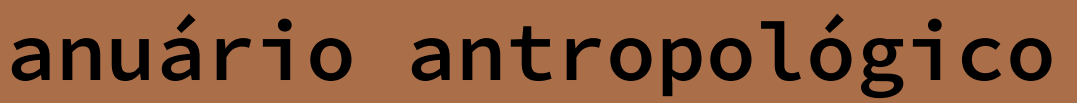 \\ (c) (i) \\ v. $46 \cdot n^{\circ} 3 \cdot$ setembro-dezembro $\cdot 2021.3$
}

\section{Disgust, humiliation and shame in the everyday life of homeless crack users}

DOI: https://doi.org/10.4000/aa.8929

\author{
Taniele Rui \\ Universidade Estadual de Campinas, Instituto de Filosofia e Ciências Humanas, Departa- \\ mento de Antropologia, Campinas, SP - Brasil \\ Professor at the Anthropology Department at Unicamp, she has been dedicated to ethnographic research \\ on precarious lives and borderline situations, producing cross-cutting investigations on poverty, vulnerabi- \\ lity, and urban marginality, having among her empirical specialties the political interfaces of the associa- \\ tion between the street, drugs, peripheries, and social welfare, public health, and punishment devices, \\ such as prisons and Therapeutic Communities.
}

From long empirical work with homeless crack users, I approach aspects related to the field of sensations and emotions, especially in situations and reports that involve disgust, humiliation and shame. Although of different sensitive and practical manifestations, these emotions address multiple demotion practices, central to comprehend how repudiation is practiced and felt and how it models, in dialogue with Judith Butler, policies of affect and recognition. 
The notion of abject bodies, as announced by Judith Butler in Gender trouble (2003) and developed in Bodies that matter (2002a), inspired the reflections I made with homeless crack consumers (Rui, 2014a). The joint reading of these works, and considering, with Butler (2002b), the incommensurability between the theory of abjection and its empirical examples, this concept leads to two problems: 1) on one side, the terrain of bodies that are unintelligible, unthinkable, not worthy of living; and 2) on the other, the idea of an outdoor constitution, that is, the idea that the subject is not out of social life, but a part of the standard production and its readability. From these problems, emerges the proposition that normativity requires the simultaneous production of abjection, constituting an economy of repudiation that operates violently, with a hierarchical ideal that subjects and bodies have different values. What is questioned is humanity itself, given that "the construction of the human is a differential operation that produces the more and the less "human," the inhuman, the humanly unthinkable" (Butler, 2002a, p. 26).

Complemented by other reflections, especially those arising from Julia Kristeva (1982) and Mary Douglas (1976), I mobilized the productive dimension of abjection, that is, its ability to produce effects. I took this as a perspective to describe bodily, political, and spatial dynamics observed from contact with drug consumers. In this sense, abjection of those who use crack - far from being considered an attribute of the subject - refers to a relational field, consisting of material and symbolic operations that model readings of subjects, bodies, and actions to the extent that they produce orderings and territories.

Such notion was updated and underwent important developments in Butler's later texts such as Precarious life (2011) and, in the continuing set of articles, Frames of war (2015). In them, the idea of precariousness - and of life as precarious - is expressed as a condition of politically induced interdependence, intelligible from the frameworks that modulate the apprehension of certain lives as amenable to mourning and of certain subjects as amenable to recognition, implying different exposures to risk and violence. The fact that certain bodies and subjects are removed - by others - from the framed space of law, protection and affect presupposes that being recognized as a subject is not a universal quality of individuals. Michael Feola (2014) understands well that the notion of precarious lives proposed by Butler challenges sovereign models of person, in favor of a strong thesis of dependence ("precariousness implies living socially, that is, the fact that one's life is always in some sense in the hands of the other"; Butler, 2015, p. 28). In this sense, to affirm that life is precarious is to affirm that maintaining life requires support and enabling conditions, and not only an internal desire to live.

Thus, if the social is made up of frameworks through which one understands the life of some and one does not understand the lives of others as lost or injured, those thrown out constitute a scrap of life - suspended and spectral - that disturbs normative instances, reinforcing them, on the one hand; and representing the possibility of their collapse, on the other. Feola also notes that the most interesting thing about this proposal is that the play of social hierarchies is incomplete without understanding how people are "thrown out". 
I briefly resume this discussion because this dossier allowed a retrospective look at my own work and a return to a topic that organized the main arguments of my doctoral thesis - abjection (Rui, 2014a). In addition to this work, I produced two other ethnographic studies on the interfaces between crack consumption and homelessness, totaling more than a decade of research about crack consumption in Campinas, São Paulo and Rio de Janeiro ${ }^{1}$; since then, I have been following what I consider an already consolidated ethnographic production on the subject, with thematic approaches that follow the very historicity of crack as a public problem in the country.

Comprehensively, I consider that there are six axes among the most highlighted by this production (in which I am included): 1) the understanding of the figure of the radical crack user as an urban phenomenon, identified through pejorative categories such as "noia" ("junkie") (Gomes; Adorno, 2011; Rui, 2014a), "noiado" (“addict”) (Cruz; Costa, 2017) “cracudo” (“crack head”) (Brandão; Conceição, 2015; Lopes, 2015; Veríssimo, 2015), "sacizeiro"2 (Malheiros, 2013); 2) the description of the dynamics, and the "flow" regarding itinerary territories that have been called "cracolândias" ("cracklands") for connecting the drug, subject, market, service, and law enforcement (Alves; Pereira, 2021; Frugoli Jr.; Sppagiari, 2010; Frugoli Jr.; Cavalcanti, 2013; Frugoli Jr.; Chizzolini, 2017; ; Medeiros, 2010; Raupp; Adorno, 2011; Rui, 2014b, 2016, 2019; Rui; Mallart, 2015b); 3) the analysis of drug policies, both those effected at the tip with consumers, locked in contact with teams and arm reduction services (Alves, 2017; Araujo, 2017; Calil, 2015; Rui, 2014a; Valim, 2015), and those glimpsed from the labyrinthine plot of attention and therapeutic dispute on crack and the street as problems to be dealt with (Carriconde, 2019; Fromm, 2017; Martinez, 2016; Mattar, 2016; Menezes, 2016; Oliveira, 2012); 4) the criticism of incriminating and repressive processes that increasingly shape the daily life and profile of the street population of the country (Canonico; Melo, 2016; Mallart; Rui, 2017; Melo, 2016; Teixeira; Matsuda, 2012); 5)the study of collective and political mobilizations that enable the existential and spatial resistance of these subjects and territories in cities (De Lucca, 2016; Melo, 2017; Rui, 2013; Magalhaes, 2016; Costa, 2017; Lemoes, 2017); and, more recently, 6) attention to the situation of women (Fernandes, 2019; Malheiros, 2019), with special focus on the period between pregnancy and puerperium, due to the withdrawal of custody of these babies (Alves, 2018; Lima, 2018; Sarmento, 2020).

From this range of studies, I assessed that few studies address the subjective aspects of the crack experience. Likewise, I consider that a lot of progress still needs to be made in the field of sensations, emotions and moralities - themes that already tangent works that deal with family relationships and family senses built on the streets (Castro, 2020; Sanctis, 2018) - which, in general, received little descriptive and analytical investment. If it is still scarce in Brazil, these themes already figured as concerns of Phillippe Bourgois, in the inspiring work In Search of respect, at the peak of the "crack epidemic" in New York during the 1990's.
1 I highlight the three surveys: i) search "Abject bodies: Ethnography in crack use and trade scenarios", funded by FAPESP and produced between 2007-2012 in crack use scenes in the cities of Campinas and São Paulo. This research resulted in my PhD thesis, later published as a book (Rui, 2014a); ii) the research "From Luz to Avenida Brasil: crack at the center of contemporary urban issues" produced in the framework of two postdocs between 2013-2015, funded by the DSD program and CAPES, in which I proposed to observe contrastively the space stigmatized as "Cracolândia", in São Paulo, and the crack consumption scene in the complex of "Favelas da Maré", in Rio de Janeiro (Rui, 2016, 2018a and 2019); iii) and the research "Evaluation of the Open Arms Program of the city of São PauIO", funded by The Open Society Foundation (Rui; Fiore; Tófoli, 2015a; Rui, 2018b) to evaluate a program attempted by the São Paulo City Council, under the PT management of Fernando Haddad (2013-2016). In all these studies, mediating agents from the territories made it possible for me to enter the field and to have close contact with the drug users. To all, I thank you enormously.

2 Translator's note: Sacizeiro is a slang that refers to 'Saci,' a Brazilian folklore character that is frequently represented smoking a pipe. 
To contribute with reflections on these themes, this text reviews ethnographic and literary materials (Athayde, 2005; Clegg, 2011) that are very powerful because they give a flesh narrative to the analyzed feelings. I am guided by the (micro) political dimension of emotions (Coelho, 2010; Oliveira, 2019) that involves considering that emotions and sensations are "taxations of power relations between social groups, simultaneously serving to express and strengthen such relations" (Coelho, 2010, p. 268). In this sense, they are privileged access to understand the social world (Victore; Coelho, 2019), and, in relation to the proposed discussion, through them, it is possible to grasp how repudiation is practiced and how it models the frames of affect.

As a part of populations perceived as "more questionably alive, perhaps even socially dead (...), or as living figures of the threat to life" (Butler, 2015, p. 70), it does not take much to imagine - and note - that living on the streets using crack implies being subject to many types of abuses, violations and violence (architectural, symbolic, physical and political), perpetrated by various actors (citizens, drug dealers, police officers, public policy agents, etc.). The most immediate emotions related to the notion of abjection are oriented around disgust and disregard; emotions that are statements of superiority (Miller, 1999) and that play a central role in the hierarchization of spaces and bodies (Ahmed, 2004).

In addition to these, more comprehensive, two others also stood out during my fieldwork: humiliation and shame. Both constitute experiences of being placed in an inferior or demeaning situation; humiliation, as Ian Miller (1993) states, belongs to the set of emotions that establish a moral ranking of hierarchies, while shame is the intimate response to the disapproval of others, a failure to adhere to the community standards to which one is committed. As the reading of Sara Ahmed (2004) summarized, the first involves judgment, the second expresses the feeling of being judged.

By empirically addressing disgust, humiliation and shame, this article operates in a more nuanced way with the notion of abjection to reflect how frameworks and policies of recognition are produced (also) through emotions. And how, when examined, they show multiple ways of producing dehumanization.

\section{DISGUST}

In his work on disgust, Ian Miller (1999) points out that disgust is a sociocultural feeling that implies moral judgment. For the author, disgust is a kind of emotion that confirms that things, people and actions are in a lower category, and, in this sense, it implies a statement of superiority over what or who is considered disgusting or despicable. With this definition in mind, I think it is possible to say that what was produced as the "crack issue" in Brazil was closely connected to the public perception about the inferiority/disgust of subjects who, with their bodies, gestures and acts seem to question the civilizing process (Elias, 1994), adopting other aesthetics, values and practices regarding hygiene, decency and intimacy.

Several links can be established between the possible effects of the radically 
consumed substance on the streets and the rejection of drug users. More than the mere assumption of stigma, my hypothesis is that the ultra-visibility of bodies - black bodies, as we know (Rui; Fiore; Tofoli, 2015A) - constitutes the center of several actions on the subject; this ultra-visibility "changes the tone of public life" (Bourgois, 1993), which comprehends the "despicable". Therefore, I agree with Miller (1999): it is necessary to face the concreteness of emotions such as disgust and repulsion and to give analytical attention to what exactly is considered repulsive.

When presenting the problem in his book, the author evokes an excerpt from Darwin (thought to be the first to thematize the theme) with two examples: the native who stuck his finger in the flesh he was eating; and the soup stain on a man's beard; both made him feel disgust. From these examples, Miller presents key points of his approach to disgust: in the first case, the complex feeling resulting from the association between contamination, contagion and exotisation (of course, of the colonized). In the second, the soup stain in the beard presents a man already contaminated by a character defect: the moral inability to be presentable - the requirement of being clean publicly. In both cases, disgust, the cousin of contempt, has strong political significance and it is possible to portray it as having three social functions: maintaining the hierarchy; building pretensions of superiority; alluding to the proper place in the social order.

In dialogue with other reflections on life on the streets (Frangella, 1996, 2009; Gregori, 2000; Martinez, 2011; Souza, 2017) and in shelters (Carriconde, 2019; De Lucca, 2013; Fernandes, 2018), to understand what constitutes disgusting/despicable, it is necessary to take a more careful look at dirt. On the streets, it is built from a process of a daily absence of bathing and hygiene thickened by sweat, food scraps, displacements; by daily contact with urban garbage; by bodily proximity to animals and insects; by sleeping and living close to the ground and being exposed to weather; by exhaling the smell of alcohol, cigarettes, crack, mold... In this process the feet become rough, cracked; the nails become thick; the hair becomes greasy, the skin becomes yellow, dry, full of wounds; the smell becomes uncomfortable - the descriptions of Frangella (2009) and Mallart (2019) about the repulsive character of smell are impactful, even in research situations.

Those who experience this process are not oblivious to it, hence the request - political, even - for the right to hygiene, the right to water, the right to public toilets, without, however, linking hygiene with the exit from the streets (Frangella, 2009). It is important to say that the marks of dirt relate not only to how long one is on the streets, but also to the loss of domestic ties and, sometimes, to the precarious access to social assistance service networks, which are also precarious - since bathrooms and toilets are often closed in social assistance facilities due to insufficient infrastructural maintenance.

From my ethnographic work, I listed some marks that accentuate the continued consumption of crack: marked teeth and fingers, bruised lips, hoarse voice, excessive weight loss. Allied to dirt, these marks are quite noticed by the users themselves. They are ashamed to laugh, try to remove the loose skins from their 
lips, they are bothered with the swaying voice and accurately keep track of the amount of lost kilograms. Marks that are on the surface of the skin, "body margins" (Douglas, 1976), are difficult to camouflage. When excessively exposed ultra-visible -, they indicate to users that the limits of reasonableness have been exceeded.

The result, however, is ambiguous: on the one hand, "the dirt configures them as a 'subject of the street"' (Frangella, 1996, p. 249), enabling the sense of belonging and identification with it; on the other, dirt enables the introjection of the prejudice that is projected onto them. Its opposite, hygiene, produces equally contradictory effects: it can nuance the visibility of someone who is on the streets (facilitating, for example, walking on the streets without being excessively noticed by pedestrians and police and it mitigate aggressiveness of passers-by), but it also hinders getting by on the streets (Gregori, 2000), which involves begging (Priori, 2018) and performing docility in front of services (Mattar, 2016); it even hinders the threating aspect, necessary to protect themselves (Frangella, 2009). Thus, the threshold between the clean and the dirty, the abject and the decent, is constantly managed, ambiguously, on the streets; being able to create heterogeneous types of homeless people and crack consumers.

The way they present themselves matters and it is managed by the subjects themselves. Thus, one must pay attention to how they produce and perceive their own bodies and actions, how they manage what is repelled as degradation or "loss of the traces of humanity". I consider the premise that crack users do not passively watch their own bodily wither, but they actively do this with their own bodies - which, however, should not be read as a personal project. These are everyday practices that combine drug consumption and homelessness with scarce material, social and political resources.

In short, displaying a degraded image, produced gradually from the combination of intense drug consumption, dirt, and weight loss, results in an uncomfortable and repulsive corporeality, which, as in the example of Miller (1999), is attributed to lack of character and moral flaws. Not surprisingly, in such contexts, weight gain and cleanliness indicate an attempt of rehabilitation and, sometimes, many hospital services and therapeutic communities are called - including by the subjects themselves - with the aim to stop this deterioration. To be attentive to the body is to develop the ability to observe oneself from a distance, but it is also an act of physically and morally shaping one's own person, of not succumbing to the process of dehumanization to which they are at risk.

The constant effort to remake oneself, to seek services in which some self-care is possible, makes me think that the media/alarmist figuration about the crack consumer is more an image than a materialization: it consisted, for the subjects themselves, of what one should not be, of what one does not want to be. Alves (2017) stated in his title: "we were never zombies". It is as if such an existence is so illegitimate that it cannot even be materialized (Butler, 2002a). In this sense, the notion of abjection as a relational field of modulation and framing of valued subjects and actions allowed to approach this widely uttered figure, but empirically 
taken as unthinkable, not worthy of existence. On the other hand, being aware of the different degrees of degradation made it possible to understand hierarchical relationships in drug use scenes, variable according to the involved social actors, at the same time that it opened up questions to understand feelings such as shame.

Even more complicated, the heterogeneity in crack and homelessness experiences is often homogenized when observed from a distance. When considering this encompassing and hegemonic process is important to understand how the visible effect of such corporeality produces harmful consequences for the subjects themselves, who are exposed to cursing, disdain, distancing, nuisance, avoidance, (hyper)surveillance, prejudiced images and narratives, expulsive architectural devices, vexatious police frisks, disciplinary interventions, aggressiveness, exploitation of drug sellers - in short, humiliation.

\section{HUMILIATION}

Therefore, crack users are subject to various kinds of ordinary situations that can be understood as humiliating. However, this topic does not describe them in a general way and does not focus on the humiliation as a dimension felt by these consumers. The interest here is in the dimension practiced against them. That is, the focus is not on the feeling of being humiliated, but on the act of humiliating. Therefore, I discuss interactions with subjects who, in the daily life of these consumers, often act producing humiliations: drug sellers and police, to question the different ways they exercise humiliation. In the first case, I stick to the dynamics of interpersonal relationships. In the second, to the humiliation as a technique of managing territories and populations.

Throughout my fieldwork, there were many reports of humiliation perpetrated by drug sellers on crack users, especially in the peripheral territories in which I conducted research (such as in the Paranapanema neighborhood, in Campinas; or in the Mare favelas complex, in Rio de Janeiro). The management of drug market actors in these territories was often reported; it was affected spatial demarcation of the places of circulation and concentration of drug consumers, but also situations in which drug use is prohibited and consumers are even expelled and avoided from poor neighborhoods, as occurs with the practice of interdiction described by Biondi (2011). Specific and more general conceptions about degradation, lack of control and loss of dignity are used to restrict and circumscribe use and drug users, to rate the subject and to decide on its inclusion in the economy of drug trafficking.

In this context, one understands the feeling of malaise that a damage reducer once expressed: "Crack consumers are very mistreated by drug sellers. I can't understand why they treat them like garbage, if they live off them... You're exploiting them to the fullest, you know they're addicted, and you're taking advantage... you're already making money from them, you do not need to treat them badly, like garbage". Such statement evokes the practice of humiliating as supposedly inexplicable in a situation in which the subjugated is economically exploited. If 
they earn from the sale, if they need to retain the customer, why, after all, treat them badly? Why treat them "like garbage"?

Mistreatment is even more intense in situations when local regulations are faced (such as the case of the customer who had her finger amputated for stealing inside the Maré). But, far from the exception, the ordinariness of humiliating situations is noticeable especially in exchange situations, when there is a disproportion of values operated in the transaction or valuation regarding objects that can be exchanged for crack. Objects worth 70, 50, 30 reais were easily converted into a portion of stone that costs 5 or 10 reais. Likewise, the evaluation of objects is usually a moment followed by joke, ordeal, ridicule.

To better illustrate this situation, which I so many times witnessed, I take up an account from the book Cabeça de Porco (Pig Head) (2005), on an occasion when Celso Athayde spent the night in Brasilia, in the House of Gordinha, a woman selling "merla", a byproduct of cocaine base paste. To facilitate comprehension, it is necessary to say that Gordinha sold the drug in her own home. During the night, she locked her house and consumers could only communicate with her through a hatch in one of the doors. The report:

Later, another man appeared. (...) he put his face and then his arm through the hatch. He had a check for fifty reais. Gordinha got up, took the check and started negotiating:

- Can you exchange this check for me? - he asked with a thick accent.

- Are you crazy? - said Gordinha, firmly.

- Look, there's 50 bucks there; give me five "potocas de merla" (pieces of "merla")".

This would represent a loss of $50 \%$, considering that the goods cost $\mathrm{R} \$ 5,00$. Gordinha said no, that she didn't work with checks, that she would only accept it if he got one. I was pissed at her. Damn, it was pure exploitation. The man was her client; he even said that it was not the first time he had exchanged a check and that it was good. The guy got nervous and engaged in a brief discussion with her, until she asked if he was disrespecting her. He shut up, tamed his voice, asked for the check and said he didn't want to exchange anymore. He thanked and left, ostensibly pissed. Gordinha turned to us, sat on the couch next to me, and criticized him: "these guys are very clever. They want everything easy". Really, that was another logic. (...) Then, another man knocked on the door in despair. By the way, despair was what all customers had in common. All knocks were strong. Gordinha got up, in her fighty, but at the same time welcoming, style. It always depended on the circumstances. She went to the door. The man put a black dress through the hatch, it looked new. She said she didn't want it. The guy insisted, asked for the love of God. (...)

Gordinha looked at me. She must have remembered that she had told me about this and decided to open the door.(...) The door opened and the man's hope intensified. He opened the dress - one of those that girls wear 
at 15th birthday parties. The guy trembled and could barely speak. He asked for merla, merla, merla(...)

- No! - sentenced Gordinha. And she slammed the door in his face. Before leaving he showed a dismay that I had only witnessed in funerals. Gordinha was rude, but I learned to accept it. It was not rational to be polite in such circumstances. (...)

Before I had the chance to recover, the arm of the check boy broke into the room through the hatch. He said that he was sorry and that he accepted her proposal.

She got up unwillingly and with a winning grin, like she was sure he'd come back. It was a commercial theory that I learned at the time but would like to forget. At three in the morning, a check for 50 reais is worth a maximum of five reais (or a potoca) (Soares et al., 2005, p. 28-29, emphasis added).

Athayde's account reveals a sense of confusion in the face of these commercial relations. What he initially considered an exploitation (50\% profit), for Gordinha, it meant not to fall in tricks, not to "go easy" on these consumers. In the end, the same check of 50 reais is worth 5 reais; the user accepts what Athayde understood as exploitation and still shows regret to have discussed with the seller. The second example - the dress that was refused - once again reinforces, for Athayde, what he reads as apparent "irrationality" involved in these exchanges; uncontested proof of "another commercial logic", always one-sided.

Although Athayde does not address the theme of humiliation, I think scenes like these evoke, precisely, humiliation. Questions like "why treat them badly?", "why treat them badly for fun?", why humiliate "unwillingly and with a winning grin"? are key to understand this issue. It is in this sense that an approach to the field of anthropology of emotions helps us to observe how acts of mistreatment and mistreatment for pleasure are moved by - and move - hierarchical social relations. On humiliation, María Elvira Díaz-Benitez wrote:

Humiliation inhabits our lives as a form of assimilation of the human, made possible by our social and historical way of perceiving the world and the subjects through hierarchies. The apprehension of hierarchies can lead us to desire the annihilation of the other in its most disastrous version, or to desire the existence of this "other", always and if it remains in its place (Diaz-Benitez, 2019, p. 69).

As an exercise in degrading, humiliation, the author follows, transposes the meaning that the person is subhuman, an incomplete human, as if missing parts or aspects of what makes one human in a broader sense; this incomplete human is more subject to violence. In the light of another empirical object, the fetish market, Diaz-Benitez also shows that pleasure and humiliation, far from being opposites, can converge in many different ways.

This observation refers to another scene that was described to me by another 
damage reducer, in the context of the Central Region of São Paulo referring to police actions:

We were at the corner of Duque de Caxias and Rua x (I do not remember the name), with that tire shop, which even installed PVC pipes and constantly shoots ice water to scare users.

Suddenly most of the crack users got up and started running away, many stumbled on others, fell, quickly got up and ran again. Scared, and for our own safety, we went into a bar, so as not to be run over by the users themselves.

Already inside the bar, we saw a group of police officers wearing sportswear, but with guns in hand, practicing cooper. They chanted chants/shouts of the corporation and approached the crack users; those who did not get up were kicked until they got up and ran. A boy who had tripped and fallen, suffered another fall; this time, due to a kick that one of the police officers gave him, a scene of pure free sadism, because the officers seemed to have fun, laughing and commenting among themselves the scene that they caused.

Stunned, we tried to talk to some users, apparently calmer - who were hard to find - and they reported to us that it was not the first time this had occurred.

(e-mailed report by a damage reducer, emphasis added)

Away from media and public visibility, the cooper of military police officers and the apparent fun they had while kicking crack users suggests the fine line between humiliation and violence, especially as, sometimes, violence requires humiliation. According to Butler, it is possible to establish a continuum between mistreatment, subjugation and the condition of inferiority/vulnerability: "the body that exists in its exposure and proximity to others, to external force, to all that might subjugate and subdue it, is vulnerable to injury; injury is the exploitation of that vulnerability" (Butler, 2015, p. 93).

The idea of "free sadism", launched by the narrator, helps thicken the analysis. In Sacher-Masoch, Deleuze (2001) notes that nothing is more alien to the sadist than the intention to dissuade, to convince or to be pedagogical, what would be at stake is "the most amazing development of demonstrative faculty": a demonstration that is confused with the omnipotence of the demonstrator and that highlights the relationship between violence and demonstration. In this sense, sadism does not target the pain of the other, but the triumph of the perpetrator. The narrator even added to sadism the term "free", an idea that seems to broaden sadism itself and contrasts with the previously described commercial exchange practices.

Miller (1993) operates with the classification of humiliation with capital $\mathrm{H}$ and lowercase $h$. While the first showcases obvious humiliations, often practiced by state actors, such as torture and spectacular violence (which often gain public visibility); the second displays everyday gestures of diminishing. I think the scenes 
mentioned touch more on that second aspect. The brief follow-up of news reports, however, shows many other situations of humiliation, promoted especially during police operations, which show how both types of humiliation are present in the daily lives of these subjects. I chose to focus on the less visible, but it is important to point out, as Rangel (2020), that governance that focuses on humiliation does not distinguish these features.

The practice of drug sellers seems to ratify a play of hierarchizations, of establishing differences in social positions within the retail trade, in the daily life of neighborhoods and in the conjuncture of the exchange. Without trying to justify it, it should be remembered that its full meaning implies a broader process of structural marginalization. In this sense, the analysis of Phillipe Bourgois (1993, p. 114-171) on the humiliation suffered/felt by crack sellers in the formal labor market is precise. Those who humiliate are also humiliated in other circumstances.

Within the focus of this article, it seems to me that humiliation acts as subjective distance, similar to that described by Rangel (2020) when analyzing the acts perpetrated by prisoners on prisoners accused of sexual crimes, "it is a desire not to be, an almost desperate desire not to be mistaken for one of them" (Rangel, 2020, p. 173). The demarcation of place and distance is evident in Gordinha's question: "are you disrespecting me?". At the same time, in scenarios marked by the convenience of the exchange, it seems to be a diminishing practice that requires the permanence of the subjugated, "as long as it stays in its place" (Diaz-Benitez, 2019, p. 60).

As I gradually understood, on the part of users, to endure this humiliation means to be able to go on with life and guarantee the drug in an environment where social relations are better known, sedimented and controlled, either by time or by kinship. Adopting a posture that is in accordance with the established implies not to lose valued social relations, not to lose oneself in the consumption of the drug (since many eyes focus on body condition) and, above all, not to be condemned to wandering.

The situation of police violence adds another element. I agree with Rangell's (2020) reading of Miller (1993): it is necessary to preserve some remnant of humanity of the victims so that they feel degraded, at the lowest limit of the social hierarchy, after all, "there is no thrill in making a rat act like a rat. The thrill is in making the human a rat" (Miller, 1993, p. 166). Such humiliation seems to not only claim a high moral status, but to state that the victim's status of humanity is absurd. Therefore, humiliation is the consequence of wanting to live where and according to what one has no right to.

As I have also learned, to endure this humiliation is to choose to give vent to the desire for wander (Perlongher, 2008) and to bodily abdication, for being close to central locations allows both various types of small gains and access to health and social assistance services. Not always paradoxically, inhabiting the last place where they were allowed to stay. 


\section{SHAME}

Shame, as defined by Agnes Heller (2003), is a painful feeling; it is a social affection - a reactive social affection: it is a reaction to something, in particular, situations. It is not a condition, but a feeling of being exposed to the eyes of the Other, which can be internalized and act as moral judgment. Thomas Scheff (2000), while reviewing the feeling of shame in social theory, notes that, unlike the guilt that falls on an action, shame is on the self, on what someone is; it involves feelings of rejection, failure, inadequacy. It is, therefore, a social emotion that reaffirms the interdependence between people. Norbert Elias (1994) took shame - specifically the changes in the threshold of embarrassment - as the key component of the civilizing process and of modernity.

When crack users told me the humiliations they suffered, I heard countless times the expression "look at my situation" to indicate shame and embarrassment due to body deterioration, especially on occasions that involved contact with relatives and dear, respected people. I heard a daughter refuse her mother's visit, because she did not want her mother to see her "in this situation", I also saw a man who refused his brother's contact, "imagine what he will feel if he sees me in this situation". The examples are several. But, in all the statements, I was struck by the fact that the expression "in this situation" seemed to be self-evident, as if it were so obvious that it did not require further explanation.

As if, when uttering it, the interlocutor knew what it was about and somehow agreed with it, since body image appeared in the foreground, it stood out, after all, it cannot be denied that discourses inhabit and accommodate themselves in bodies (Butler, 2002a). In this sense, only by pointing or indicating themselves, drug users found a way to say what embarrassed them so much: the situation they arrived at. In the way they observed it, this bodily situation materialized the choices they made throughout life, the involvement with the substance, homelessness; it materialized, above all, what they subjectively internalized as a moral failure. Far from configuring only an analytical construct, looking at these bodies "in this situation" is a condition for understanding these social actors.

Genivaldo, a black man in his 50s, once told me, in a state of drunkenness, that he had left the "cracklands", around the Luz station, to take a walk around the center of São Paulo. In Patriarca square, surprisingly, he found an acquaintance from his hometown, and he then hid behind a pole to avoid being identified. Describing what happened, he recalled that both studied together during the first three years of school - the only ones formally attended by him, after them, he had to help his father in rural work.

The sudden encounter with this acquaintance was a kind of trigger for Genivaldo to revive the memory of a series of facts from the past, which, to me, seemed to be connected in an attempt to explain the very different paths taken by the two. The acquaintance had a better life condition, "he was of a family that everyone knew in the city, who attended church, who had a car". A family of four people, "small", according to Genivaldo. Different from his, numerous, "only with father 
and seven brothers". His mother died when he was five years old, during the birth of his younger brother. The acquaintance continued to attend school, then, he went to study in a nearby, larger city. Genivaldo, at that time, was already tired of working with his father in the field and aimed to be a football player. The acquaintance grew older, studied "to become an accountant", married, formed a family and lived in a good house. Genivaldo decided, at the age of 23, to come to São Paulo to find work in one of the factories that "people said gave good employment, registered, you know?" Without having any formation that could give him access to such a job, he worked as a general assistant in various firms, but never managed to stabilize himself. He was either fired or quit. He was married for four years, but he drank a lot. The woman broke up the marriage and, according to him, he was kicked out before they had a child. After this comparative retrospective, Genivaldo reflected:

You see how things are, right? This acquaintance tried hard, studied, managed to have a good, normal life, he is well-dressed and there he is, right man? Working honestly, walking decently. What about me? I wear these clothes that you're looking at now, I drink like a convict, I use crack from time to time, I know the crackheads...

I should not have left here, I should not have gone for a walk around the city, because here in these streets everyone is more or less the same, halffailed like me and we kind of know that, we understand each other that way.

Genivaldo made such considerations with watery eyes. I tried to argue that his life was harder than that of his acquaintance. He, however, was insistent in saying that he was a failure and stubborn in making me observe "his situation", which was so clear to him. "Look at my situation", "look at my situation", he cried. Sitting on the sidewalk, leaning his back against a wall, he was dirty and wearing torn clothes, his eyes rather remelted, reddened, and his eyelids swollen. He was not thin, on the contrary, he had a rather swollen belly that gained bulge on the already clinging sweater. For two or three times he repeated being "much more into" alcohol than crack, but that, given his current "situation", he preferred to stay with the "crackheads", on those streets, where everyone is "more or less the same, half-failed like me".

This speech made me observe a possibility, previously unthinkable, for the agglutination of crack consumers in the same locality. It also made me apprehend how shame, by internalizing judgments of others, is lived as a barrier to free movement through the city. Although it was expected that not everyone in the drug scene would know each other, and that they attend it due to different interests, the idea that many could share a tacit feeling of having common stories and trajectories of "failures" offered another perspective for this practice of inhabiting the city. Along with similar people, "the situation" did not have to be contrasted all the time. It not only minimized shame but made it possible to share it. In reading Helen Lynd's work, Scheff (2000) shows how sharing shame strengthens the bond 
between people.

In a completely different experience and setting, Bill Clegg's autobiographical narrative ${ }^{3}$ corroborates this possibility:

I walk into the chic, quiet lobby and approach the front desk. (...) He [the receptionist] immediately says, "I'm sorry but there is nothing here for you" (...) It takes a few beats for me to fully take in what is happening(...). I have somehow, without seeing it happen, tripped over some boundary, from the place where one can't tell that I'm a crack addict to the place where it is sufficiently obvious to turn me away. I look at my hands to see if they are shaking. Suddenly, for the first time, I feel as if I might look and act and sound in a way that I am not able to see. Like body odor or bad breath that is only detectable to other people, my movements and my whole bearing could be invisible to me. I try to figure out if people are staring. If they are registering disgust as they walk past. My pants feel very loose. It's been over a week since l've had a new hole punched in my belt, and my navy turtleneck hangs stretched and baggy off my frame and must, it just must, reek. Though I have been doing drugs, drinking liters of vodka a day, not sleeping, and running from hotel to hotel for a month, it dawns on me like a great shock that I might actually look like a junkie. I feel that whatever capacity I'd once had to move through the world undetected has vanished, that CRACK ADDICT is written on my forehead in ash, and everyone can see. (...)

I remember a building, some kind of subsidized housing development on 23rd Street, where I had once seen what I thought were junkies. The memory flashes through me like a strobe of hope. (...)

I pick up my pace and when I hit 23rd Street, head east toward Second. I see the used-furniture shop and then see the building. I can also see - how can I say this? - my kind, everywhere. Shuffling here and there. Leaning against buildings. Arguing into pay phones. They might as well all be dressed in bright orange jumpsuits, they stand out so clearly to me. I exhale and begin to relax. I lean up against the building and let the sun hit my face. The warmth feels wonderful and it's a relief to stop moving. I feel safe for the first time all day. (Bill Cleg, Portrait of an addict as a young man, emphasis added)

The bodily transformation of which users are ashamed and avoid exposing themselves to acquaintances is seen as a moral failure, understood as loss of dignity. However, Bill Clegg's description shows a moment in which corporeality becomes radicalized: when, suddenly, he stumbles upon "some boundary" marked by this specific corporeality that, like those in "orange jumpsuits", is too strong not to be noticed. Being on the other side of this "boundary", as the writer notices, limits one's ability to move freely around the world without being banned, observed, or judged. Only then, one sees the importance of the places of reunion; once in
3 Bill Clegg's book was published in the United States in 2010, when he had already been clean of crack for five years. After receiving praise from American literary critics, it was translated into Portuguese and published, in 2011, in Brazil by Companhia das Letras. Clegg focuses on offering, with literary merit, "only" details of his crack consumption, the transformation of his body and the loss of all his money. Brief fragments access his past. 
them, there is the relief of moving around without having to confront yourself, your choices, and others all the time; the comfort of stopping, looking at the sun and, at least once in the day, feeling "safe".

Shame is a painful emotion. Although it is relevant to say that drug consumption does not necessarily imply suffering, in the case of radical crack consumption in street situations, however, it is a type of emotion that, to me, has never allowed the interpretation of consumption as an individual option, detachment or refusal from the social world. On the contrary. The feeling of shame indicates the introjection of external judgment. But more than that. The other side of shame is that it also allows the subjects to look back at themselves. In other words, body stripping, or self-denial, should not be confused with a total absence of concern for the self-image or the image they present to others, because it is in the very process of noticing that their bodies shock those who see them - when experiencing shame - that they try, even if failing multiple times, to remake themselves. After all, the "situation", with the subjective and political force contained in it, is always seen as transitory, as a state that struggles to reverse itself.

\section{FINAL CONSIDERATIONS}

As I approached the field of Anthropology of emotions and sensations, paying attention, as Scheff (2000) suggests, to their different forms, manifestations and consequences, I returned to ethnographic and literary materials to describe social processes that fabricate non-recognition. At the end of the above, I believe it is possible to resume the dialogue with Butler. My reading is that, between the notion of abjection and precariousness, she advances in the sense of proposing an apprehension of life not as ontological, but as dependent on social and political conditions to be livable; and that, through the idea of frameworks, it nuances the way in which the norm differentiates lives as amenable and not amenable to recognition.

In Butler's analysis, emotions occupy a central role in the politics of affect and indignation, given that "the tacit interpretive scheme that divides worthy from unworthy lives works fundamentally through the senses” (Butler, 2015, p. 83). Interested in understanding how the play of social hierarchies works and how people are thrown "out", I worked with three hierarchizing emotions (disgust, humiliation and shame), to address the multiple ways of diminishing.

In the case of homeless crack consumers, I think that the framework is marked mainly by the corporeality considered degraded or repulsive. Not because it is, in itself, abject, but because, associated with a moral fault, it is seen as out of the norm. In this sense, it seemed important to describe not only how such corporeality is produced, but above all, how it is managed in the streets. I considered both the internal heterogeneity of crack use scenes and the encompassing process that homogenizes them. Between one and the other, it is possible to question and tension the place - especially the effects - of the frame. In parallel with the hegemonic project of dehumanization, there is also a complex process of identity 
construction and differentiation. The fieldword shows many ways to dehumanize.

Situations of humiliation, as I showed, can connect to both. Attentive to the field of personal interrelationships between crack consumers and dealers, it was possible to glimpse how the effort to produce subjective distancing (Rangel, 2020) supposes a process of demotion that is not concluded simply by "expelling", but sometimes by maintaining these individuals inside social relations in the lowest positions. In the case of the humiliation promoted by state actors, I think that it focuses on the "scrap of life" imposed on subjects perceived as dishonoring their own humanity, at the same time that it acts as a technique of managing territories and populations.

Shame, in turn, is even more ambiguous. It implies a desire to adapt to the norm, it reflects the suffering experienced by not being able to be recognized as a subject. It involves more intimate perceptions about discomfort and failure. At the same time, it is a tie between the subjects and the very humanity that is denied to them. By recognizing humanity in oneself, by observing that this feeling can be tacitly shared with others in a similar "situation", there is also the possibility of remaking oneself.

Over a decade of monitoring the public debate on crack, I think that state violence has intensified. At the same time, emotional grammars on the subject have changed drastically, especially in the promotion of a policy of affect to reduce disgust and amplify indignation. The times are rough and the work must go on, because, to change the frameworks "the senses have to be operative, which means that a struggle must be waged against those forces that seek to regulate affect in differential ways" (Butler, 2015, p. 83). Within the limits of academic reflection, I hope that this article, like the letters that evade the prison of Guantanamo, will expand affect and, among other things, provoke "a more generalized horror and outrage that will support and impel calls for justice and an end to violence" (Butler, 2015, p. 23). 


\section{References}

AHMED, Sara. The cultural politics of emotion. Edinburg: Edinburg University Press, 2004.

ALVES, Ariana O. Quem tem direito a querer ter/ser mãe? Dinâmicas entre gestão, instâncias estatais e ação política em Belo Horizonte - MG. Dissertação (Mestrado em Antropologia Social) - Universidade Estadual de Campinas, Campinas, 2018.

ALVES, Ygor. Jamais fomos zumbis: contexto social e craqueiros na cidade de São Paulo. Salvador: EDUFBA, 2017. Disponível em: https://www.revistas.usp.br/ra/article/view/ 184481. Acesso em: 28 ago. 2021.

ALVES, Ygor; PEREIRA, Pedro P. Interações, trilhas e caminhos de uma cidade em fluxo: etnografia na Cracolândia. Revista de Antropologia, v. 64, n. 1, e184481, 2021.

ARAUJO, Erick. A vida em cenas de uso de crack. Rio de Janeiro: Papéis Selvagens, 2017.

BIONDI, Karina. Consumo de drogas na política do PCC. Coletivodar.org. Disponível em: http://coletivodar.org/cartas-na-mesa-consumo-de-drogas-na-politica-do-pcc/. Acesso em: 27 jul. 2021.

BOURGOIS, Philipe. In search of respect: selling crack in barrio. Cambridge: University Press, 2003.

BRANDÃO, Beatriz; CONCEIÇÃO, Wellington. O crack, o corpo e a rua: analisando trajetos e andanças na cidade. Ponto Urbe, 20. Disponível em: https://journals.openedition. org/ pontourbe/3480. Acesso em: 28 ago. 2021.

BUTLER, Judith. Como os corpos se tornam matérias: entrevista com Judith Butler. (Entrevista concedida a Irene Prins e Baukje Meijer). Revista Estudos Feministas, v. 10, n. 1, p. 155-167. 2002b. Disponível em: https://www.scielo.br/j/ref/a/vy83qbL5HHNK dzQj7PXDdJt/?lang=pt. Acesso em: 28 ago. 2021.

BUTLER, Judith. Cuerpos que importam: sobre os limites materiais e discursivos do sexo. Buenos Aires: Paidós, 2002a.

BUTLER, Judith. Problemas de gênero: feminismo e subversão da identidade. Rio de Janeiro: Civilização Brasileira, 2003.

BUTLER, Judith. Quadros de guerra: quando a vida é passível de luto? Rio de Janeiro: Civilização Brasileira, 2015.

BUTLER, Judith. Vida precária. Revista Contemporânea, n. 1, p. 13-33, 2011.

CALIL, Thiago. Condições do lugar: relação entre saúde e ambiente para pessoas que usam crack no bairro da Luz. Dissertação (Mestrado em Saúde Pública) - Universidade de São Paulo, São Paulo, 2015.

CANONICO, Leticia; MELO, Natalia M. Distinguir entre tráfico e uso de drogas: apontamentos sobre a seletividade penal na Cracolândia". In: RUI, Taniele; MARTINEZ, Mariana; FELTRAN, Gabriel (Orgs.). Novas faces da vida nas ruas. São Carlos: EDUFSCAR, 2016. p. 223-244.

CARRICONDE, Raquel. Cair na rede: circulações desde abrigos da cidade. Dissertação (Mestrado em Ciências Sociais) - Universidade Estadual do Rio de Janeiro, Rio de Janeiro, 2019. 
CASTRO, Odilon. Negro Drama: mães, filhos e uso radical de crack. Curitiba: Apris, 2020.

CLEGG, Bill. Retrato de um viciado quando jovem. São Paulo: Companhia das Letras, 2015.

COELHO, Maria Claudia. Narrativas de violência: a dimensão micropolítica das emoções. Mana, v. 16, n. 2, p. 265-285, 2010. Disponível em: https://www.scielo.br/j/mana/a/ VqyC83wMK9HFPLFVLfHH5Vk/?lang=pt\&format=pdf. Acesso em: 28 ago. 2021.

COSTA, Roberta. Mil fitas na Cracolândia: amanhã é domingo e a craco resiste. Dissertação (Mestrado em Estudos Brasileiros) - Universidade de São Paulo, São Paulo, 2017.

CRUZ e COSTA, Julie. Entre pedras e paranoias. Dissertação (Mestrado em Sociologia) Universidade Federal de Pernambuco, Recife, 2017.

DE LUCCA, Daniel. Morte e vida nas ruas de São Paulo: a biopolítica vista do centro. In: RUI, Taniele; MARTINEZ, Mariana; FELTRAN, Gabriel (Orgs.). Novas faces da vida nas ruas. São Carlos: Edufscar, 2016. p. 3-43.

DE LUCCA, Daniel. Nem dentro, nem fora do albergue: transformações de um dispositivo da assistência. In: CUNHA, Neiva; FELTRAN, Gabriel (Orgs.). Sobre periferias, novos conflitos no Brasil contemporâneo. Rio de Janeiro: Lamparina, 2013. p. 34-48.

DELEUZE, Gilles. Presentación de Sacher-Masoch. Lo frio y lo cruel. Buenos Aires: Amorrortu, 2001.

DIAS-BENITEZ, Maria Elvira. O espetáculo da humilhação, fissuras e limites da sexualidade. Mana, n. 21, p. 51-78, 2015. Disponível em: https://www.scielo.br/j/ mana/a/ ddPwc8SPLV99896qZW4b5Zq/abstract/?lang=pt. Acesso em: 28 ago. 2021. Disponível:https://www.jstor.org/stable/40971959?seq=1\#metadata_info_tab_contents. Acesso em: 28 ago. 2021.

DOUGLAS, Mary. Pureza e perigo. São Paulo: Perspectiva, 1976.

ELIAS, Norbert. O processo civilizador. Rio de Janeiro: Zahar, 1994.

FEOLA, Michael. Norms, vision and violence: Judith Butler on the politics of legibility. Contemporary Political Theory, n. 13, p. 130-148, 2014. Disponível em: https://link. springer.com/article/10.1057/cpt.2013.15. Acesso em: 28 ago. 2021.

FERNANDES, Adriana. Mulheres pobres que amam demais: a vida material dos direitos e das políticas. Revista Contemporânea, n. 9, p. 745-770, 2019. Disponível em: https:// www.contemporanea.ufscar.br/index.php/contemporanea/article/view/778. Acesso em: 28 ago. 2021.

FERNANDES, Adriana. Quando os vulneráveis entram em cena: Estado, vínculos e precariedade em abrigos. In: BARROS, Joana (Org.). Os limites da acumulação e os movimentos de resistência no território. São Carlos: EDUSP, 2018. p. 85-99.

FRANGELLA, Simone. Capitães do asfalto: a itinerância como construtora da sociabilidade de meninos e meninas de rua de Campinas. Dissertação (Mestrado em Antropologia Social) - Universidade Estadual de Campinas, Campinas, 1996.

FRANGELLA, Simone. Corpos urbanos errantes: uma etnografia da corporalidade de moradores de rua São Paulo. São Paulo: Annablume, 2009.

FROMM, Deborah. O "fim da Cracolândia”: etnografia de uma aporia urbana. Dissertação (Mestrado em Antropologia Social) - Universidade Estadual de Campinas, Campinas, 2017.

FRUGOLI JR, Heitor; CAVALCANTI, Mariana. Territorialidades da Cracolândia em São Paulo e no Rio de Janeiro. Anuário Antropológico, n. 38, p. 73-97. 2013. Disponível em: https://journals.openedition.org/aa/561. Acesso em: 28 ago. 2021. 
FRUGOLI JR, Heitor; CHIZZOLINI, Bianca. Relations between face-to-face ethnography and images from Google View: a research into crack cocaine users of the streets of São Paulo's inner city. Revista do GIS, n. 2, p. 11-36, 2017. Disponível em: https:// www.revistas.usp.br/gis/article/view/129197. Acesso em: 28 ago. 2021.

FRUGOLI JR, Heitor; SPPAGIARI, Enrico. Da Cracolândia aos nóias: percursos etnográficos no bairro da Luz. Ponto Urbe, n. 12. 2011. Disponível em: https://journals. openedition.org/pontourbe/1870. Acesso em: 28 ago. 2021.

GOMES, Bruno; ADORNO, Rubens. Tornar-se “nóia”: trajetória e sofrimento social nos "usos de crack" no centro de São Paulo. Revista Etnográfica, v. 15, n. 3, p. 569-586, 2011. Disponível em: https://journals.openedition.org/etnografica/1076. Acesso em: 28 ago. 2021.

GREGORI, Maria Filomena. Viração: experiência de meninos nas ruas. São Paulo: Companhia das Letras, 2000.

HELLER, Agnes. Five approaches to the phenomenon of shame. Social Research, v. 70, n. 4, p. 1015-1030, 2003.

KRISTEVA, Julia. Powers of horror: an essay on abjection. Nova York: Columbia University Press, 1982.

LEMÕES, Tiago. De vidas infames à máquina de guerra. Tese (Doutorado em Antropologia) - Universidade Federal do Rio Grande do Sul, Porto Alegre, 2017.

LIMA, Michele. A quem pertence essa gravidez? Reflexões sobre maternidade/maternagem de mulheres que fazem uso de drogas e as agentes do estado. Dissertação (Mestrado em Ciências Sociais) - Universidade do Estado do Rio de Janeiro, Rio de Janeiro, 2018.

LOPES, Mariana. No meio das notícias tinha uma pedra. Dissertação (Mestrado em Comunicação) - Universidade Federal do Rio de Janeiro, Rio de Janeiro, 2015.

MAGALHÃES, Taís. Campos de disputa e gestão do espaço urbano: o caso da Cracolândia paulistana. Dissertação (Mestrado em Sociologia) - Universidade de São Paulo, São Paulo, 2021.

MALHEIROS, Luana. Entre sacizeiro, usuário e patrão: um estudo etnográfico sobre consumidores de crack no centro histórico de salvador. In: MACRAE, Edward (Org.). Crack: contexto, padrões e propósitos de uso. Salvador: EDUFBA, 2013. p. 223-314.

MALHEIROS, Luana. Tornar-se mulher usuária de crack: trajetória de vida, cultura de uso e políticas sobre drogas no centro de Salvador - BA. Tese (Doutorado em Antropologia) - Universidade Federal da Bahia, Salvador, 2019.

MALLART, Fabio; RUI, Taniele. Cadeia ping-pong: entre o dentro e o fora das muralhas. Ponto Urbe, n. 21. 2017. Disponível em: https://journals.openedition.org/pontourbe/ 3620. Acesso em: 28 ago. 2021

MALLART, Fabio; RUI, Taniele. Findas linhas: circulações e confinamentos pelos subterrâneos de São Paulo. Tese (Doutorado em Sociologia) - Universidade de São Paulo, São Paulo, 2019.

MARTINEZ, Mariana. Andando e parando pelos trechos: uma etnografia das trajetórias de rua em S. Carlos. Dissertação (Mestrado em Antropologia) - Universidade Federal de São Carlos, São Carlos, 2016.

MARTINEZ, Mariana. Redes do cuidado: etnografia de aparatos de gestão intersetorial para usuários de crack. Tese (Doutorado em Antropologia) - Universidade Federal de São Carlos, São Carlos, 2016. 
MATTAR, Marina. No labirinto: formas de gestão do espaço e das populações na Cracolândia. Dissertação (Mestrado em Sociologia) - Universidade de São Paulo, São Paulo, 2016.

MEDEIROS, Regina. Clínica e croni(cidade): impactos do uso/abuso de crack na configuração urbana e nos tratamentos da toxicomania. In: SAPORI, Luis Flavio; MEDEIROS, Regina (Orgs.). Crack: um desafio social. Belo Horizonte: Editora PUC Minas, 2010. p. 165-218.

MELO, Tomás. Mundos que refugam, rua como refúgio: reconfigurações do perfil social da população em situação de rua. Revista Florestan Fernandes, v, 3, n. 10, p. 10-31, 2016. Disponível em: http://www.revistaflorestan.ufscar.br/index.php/Florestan/ article/ view/161. Acesso em: 28 ago. 2021.

MELO, Tomás. Política dos Improváveis: percursos de engajamento militante no Movimento Nacional da População em situação de rua. Tese (Doutorado em Antropologia) - Universidade Federal Fluminense, Niterói, 2017.

MENEZES, Leticia. Entre a saúde e a repressão: políticas públicas na região da Cracolândia - SP. Dissertação (Mestrado em Saúde Pública) - Universidade de São Paulo, São Paulo, 2019.

MILLER, William Ian. Anatomía del Asco. Buenos Aires: Taurus, 1999.

MILLER, William Ian. Humiliation: and other essays on honor, social discomfort and violence. Ithaca: Cornell University Press, 1993.

OLIVEIRA, Leandro. A vergonha como uma ofensa: homossexualidade feminina, família e micropolítica das emoções. Horizontes Antropológicos, n. 25, p. 141-171. 2019. Disponível em: https://www.scielo.br/j/ha/a/FJ9DqKDWH3BHx5kJ3yWVztf/abstract/? lang=pt. Acesso em: 28 ago. 2021.

OLIVEIRA, Luciano. Circulação e fixação: o dispositivo de gerenciamento dos moradores de rua em $\mathrm{S}$. Carlos e a emergência de uma população. Tese (Doutorado em Sociologia) - Universidade Federal de São Carlos, São Carlos, 2012.

PERLONGHER, Nestor. O negócio do michê: a prostituição viril em São Paulo. São Paulo: Fundação Perseu Abramo, 2008.

PRIORI, Josimar. A construção da cidade: a vida nas ruas, religião, voluntariado e Estado. Tese (Doutorado em Sociologia) - Universidade Federal de São Carlos, São Carlos, 2018.

RANGEL, Everton. Depois do estupro: homens condenados e seus tecidos relacionais. Tese (Doutorado em Antropologia) - Universidade Federal do Rio de Janeiro; Museu Nacional, Rio de Janeiro, 2020.

RAUPP, Luciana; ADORNO, Rubens. Circuitos de uso de crack na região central da cidade de São Paulo. Ciência e Saúde Coletiva, v. 16, n. 5, p. 2613-2622, 2011. Disponível em: https://www.scielo.br/j/csc/a/vCGLjS5jHjRGXpPLGZNfxqQ/?format=pdf\&lan$\mathrm{g}=$ pt. Acesso em: 28 ago. 2021.

RUI, Taniele. Da deriva pela Av. Brasil à fixação numa esquina na Maré: usuários de crack, refugiados da pacificação. In: FARIAS, Juliana (Org.). Militarização do Rio de Janeiro: da pacificação à intervenção. Rio de Janeiro: Mórula, 2018a. p. 57-69.

RUI, Taniele. Depois da Operação Sufoco: sobre espetáculo policial, cobertura midiática e direitos na Cracolândia paulistana. Revista Contemporânea, n. 3, p. 287-310, 2013. Disponível em: https://www.contemporanea.ufscar.br/index.php/contemporanea/ article/view/144/80. Acesso em: 28 ago. 2021. 
RUI, Taniele. Fluxos de uma territorialidade: duas décadas de "Cracolândia" (19952014). In: KOWARICK, Lucio; FRUGOLI JR, Heitor (Orgs.). Pluralidade urbana em São Paulo: vulnerabilidade, marginalidade, ativismos sociais. São Paulo: Editora 34, 2016. p. 225-248.

RUI, Taniele. Nas tramas do crack: etnografia da abjeção. São Paulo: Terceiro Nome; Fapesp, 2014a.

RUI, Taniele. Pacote de direitos e Repressão na Cracolândia paulistana: dois anos do Programa De Braços Abertos. In: LABATE, Beatriz; RODRIGUES, Thiago (Orgs.). Políticas de drogas no Brasil: conflito e alternativas. Campinas: Mercado de Letras, 2018b. p. 311-340.

$\mathrm{RUI}$, Taniele. Por entre territórios visíveis e territórios invisibilizados: mercados ilícitos e cracolândias de São Paulo e Rio de Janeiro. Novos Estudos CEBRAP, n. 38, p. 573-578, 2019. Disponível em: https://www.scielo.br/j/nec/a/CdVVGLhMj6NfdRd4LzCSdbh/? lang=pt\&format=pdf. Acesso 28 Aug 2021.

RUI, Taniele. Usos da "Luz" e da "Cracolândia": etnografias de práticas espaciais. Saúde e Sociedade, v. 23, n. 1, p. 91-104, 2014b. Disponível em: https://www.scielo.br/j/ sausoc/a/76QCVrYP59pNsr9XX5pmymg/?lang=pt\&format=pdf. Acesso em: 28 ago. 2021.

RUI, Taniele; FIORE, Mauricio. TOFOLI, Luis Fernando. Pesquisa de avaliação preliminar do Programa De Braços Abertos. Plataforma Brasileira de Políticas sobre Drogas/ Instituto Brasileiro de Ciências Criminais, São Paulo: PBPD, 2015a. Disponível em: http://fileserver.idpc.net/library/PESQUISA\%20DE\%20BRA\%c3\%870S\%20 ABERTOS.pdf. Acesso em: 28 ago. 2021.

RUI, Taniele; MALLART, Fabio. A Cracolândia, um potente conector urbano. Le Monde Diplomatique, n. 99. 2015b. Disponível em: https://diplomatique.org.br/a-Cracolândia-um-potente-conector-urbano/. Acesso em: 28 ago. 2021.

SANCTIS, Raiza B. Crack, casa, família: uma etnografia sobre cuidados, (des)afetos e emoções. Dissertação (Mestrado em Antropologia) - Universidade Estadual de Campinas, Campinas, 2018.

SARMENTO, Caroline. Por que não podemos ser mães? Tecnologias de governo, maternidade e mulheres com trajetória de rua. Dissertação (Mestrado em Antropologia) Universidade Federal do Rio Grande do Sul, Porto Alegre, 2020.

SCHEFF, Thomas. Shame and the social bond: a sociological theory. Sociological Theory, v. 18, n. 1, p. 84-99, 2000. Disponível em: https://www.jstor.org/stable/223283?seq=1\#metadata_info_tab_contents. Acesso em: 28 ago. 2021.

SOARES, Luiz Eduardo; BILL, MV; ATHAYDE, Celso. Cabeça de Porco. Rio de Janeiro: Objetiva, 2005.

SOUZA, Renata. Na maloca: um estudo sobe pessoas em situação de rua em uma praça na cidade do Rio de Janeiro. Dissertação (Mestrado em Antropologia) - Universidade Federal Fluminense, Niterói, 2017.

TEIXEIRA, Alessandra; MATSUDA, Fernanda. Feios, sujos e malvados. Le Monde Diplomatique, n. 56, 2012. Disponível em: https://diplomatique.org.br/feios-sujos-e-malvados/. Acesso em: 28 ago. 2021.

VALIM, Danielle. Os passos dos indesejáveis: um estudo do contexto sociocultural do uso e usuários de crack nas cidades do Rio de Janeiro e Nova York. Tese (Doutorado em Medicina Social) - Instituto de Medicina Social - UERJ, Rio de Janeiro, 2015.

VERÍSSIMO, Marcos. Quem são os cracudos? Apontamentos para o estudo antropoló- 
gico de um problema social. Revista Dilemas, v. 8, n. 2, p. 303-327, 2015. Disponível em: https://revistas.ufrj.br/index.php/dilemas/article/view/7294. Acesso em: 28 ago. 2021.

VICTORE, Ceres; COELHO, Maria Claudia. A antropologia das emoções: conceitos e perspectivas teóricas em revisão. Horizontes Antropológicos, n. 25, p. 7-21, 2019. Disponível em: https://journals.openedition.org/horizontes/3170. Acesso em: 28 ago. 2021. 